\title{
What is the Role of Radiology in Cardiac Masses? Imaging Findings of Different Diagnoses
}

\author{
Kardiyak Kitlelerde Radyolojinin Rolü Nedir? Farklı \\ Tanıların Görüntüleme Bulguları
}

${ }^{1}$ Necmettin Erbakan University, Meram Faculty of Medicine, Department of Radiology, Konya, Turkey

Address correspondence to: Cengiz Kadiyoran, Necmettin Erbakan University, Meram Faculty of Medicine, Department of Radiology, Konya, Turkey

e-mail: ckadiyoran@hotmail.com

Geliş Tarihi/Received: 12 July 2021 Kabul Tarihi/Accepted: 3 September 2021

\author{
Cengiz Kadiyoran ${ }^{1}$, Pinar Diydem Yilmaz ${ }^{1}$
}

\begin{abstract}
Öz
Amaç: Kardiyak kitleler nadir görülür; neoplastik ve neoplastik olmayan olarak sınıflandırılır. Kardiyak kitlelerin tanısında ve cerrahi planlanmasında farklı görüntüleme yöntemleri hayati bir rol oynamaktadır. Ekokardiyografi, kitle tespitinde birincil yöntemdir. Kardiyak kitleleri tespit etmek ve takip etmek için bilgisayarlı tomografi $(B T)$ ve manyetik rezonans görüntüleme (MRG) kullanılır. Bu çalışmada nadir görülen kardiyak kitlelerin tespiti ve tedavi planlamasında radyolojinin rolünü değerlendirmeyi amaçladık. Hastalar ve Yöntem: 2018-2021 yılları arasında radyoloji ünitemizde saptanmış kardiyak kitlesi olan beş hastanın başvuru semptomları, kitlelerin tespit edildiği görüntüleme yöntemleri ve görüntüleme bulgularının patolojik tanıları ile uyumlu olup olmadığı değerlendirildi.

Bulgular: Lenfoma, pleomorfik sarkom ve hemanjiyom tanısı alan hastaların kitleleri $3 \mathrm{~cm}$ 'den büyüktü. Malign kitlelerin sınırları belirsizdi ve komşu yapılara invazyon görülmekteydi. Kardiyak hemanjiyom, perikardiyal kist ve miksoma tanısal radyolojik bulgulara sahipti.

Sonuç: Kardiyak kitlelerin patolojik tanısına göre görüntüleme bulgularının bilinmesi hasta yönetiminde ve tedavi planlamasında önemlidir.

Anahtar Kelimeler: Kardiyak lenfoma, kardiyak hemanjiyom, pleomorfik sarkom, bilgisayarlı tomografi, kalp kitlesi

\section{Abstract}

Aim: Cardiac masses are rare and categorized as non-neoplastic and neoplastic. Different imaging methods play a vital role in the diagnosis and surgical planning of cardiac masses. Echocardiography is the primary method of mass detection. Computed tomography (CT) and magnetic resonance imaging (MRI) are used to detect and monitor cardiac masses. In this study, we aimed to evaluate the role of radiology in the detection of rare cardiac masses and treatment planning.

Patients and Methods: Admission symptoms of five patients with cardiac masses detected in our radiology unit between 2018 and 2021, the imaging methods in which the lesions were determined, and whether the imaging findings were consistent with their pathological diagnosis were evaluated.

Results: The masses of patients diagnosed with lymphoma, pleomorphic sarcoma, and hemangioma were larger than $3 \mathrm{~cm}$. The margins of the malignant masses were ill-defined, and invasion into adjacent structures was seen. Cardiac hemangioma, pericardial cyst, and myxoma had diagnostic radiological findings.

Conclusion: It is significant to know the imaging findings according to the pathological diagnosis of cardiac masses in patient management and treatment planning.
\end{abstract}

Key words: Cardiac lymphoma, cardiac hemangioma, pleomorphic sarcoma, computed tomography, cardiac mass
Cite this article as: Kadiyoran C, Yilmaz PD. What is the Role of Radiology in Cardiac Masses? Imaging Findings of Different Diagnoses. Selcuk Med J 2021;37(3): 257-262

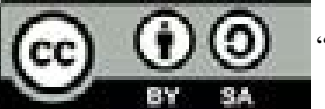

"This article is licensed under a Creative Commons Attribution-NonCommercial 4.0 International License (CC BY-NC 4.0)"
Disclosure: None of the authors has a financial interest in any of the products, devices, or drugs mentioned in this article. The research was all authors have research was not sponsored by an outside organization. All authors have agreed to allow full access to the primary data and to allow the journal to review the data if requested. 


\section{INTRODUCTION}

Cardiac masses are uncommon and can be classified as neoplastic and non-neoplastic. Neoplastic can also be categorized as primary benign tumors, primary malignant tumors, and metastases. Primary cardiac tumors are rare, and their incidence in the autopsy series is between $0.0017 \%$ and $0.28 \%$. Metastatic cardiac masses are seen 20-40 times more than primary cardiac tumors $(1,2)$. Half of the Malf of the (19\%) by lipomas (19\%) and papilary fibroelastomas (17\%). Only $25 \%$ of primary cardiac masses are malignant and mosty are sarcomas (3). Non-neoplastic structures (intracardiac thrombus, pericardial cyst, and valve vegetation) can confuse with neoplastic heart masses (4)

Imaging has a vital role in cardiac masses identification, differentiation of benign-malignant, and surgical planning.

Echocardiography is the first-choice imaging modality for cardiac masses, as it is easily accessible and does not cause contrast material and radiation exposure. It also provides the opportunity to dynamically evaluate the relationship of the tumor with the valve and pericardium. However, it may be difficult o diagnose a cardiac tumor by echocardiography in plagnose a cardiac tur Hor by echocardiography in patients with chronic lung disease and obesity. Its ability to make an overall assessment of cardiac characterization is less specific on echocardiography than magnetic resonance imaging (MRI) (5).

Cardiac MRI is the most valuable imaging modality for cardiac masses due to its superior soft-tissue for cardiac masses due to its superior soft-tissue
characterization, high temporal resolution, and characterization, high temporal resolution, and
multi-planar imaging capabilities (6). It provides a remarkable advantage in pediatric patients as it does not require the use of ionizing radiation. However, patients with pacemakers, unable to comply with the examination, and claustrophobic are not suitable for cardiac MRI. Small mobile masses may not be visible on MRI due to low spatial resolution.

Cardiac computerized tomography (CT) is an imaging modality that quickly provides highquality images with superior spatial resolution. CT can provide anatomical information, functional CT can provide anamical information, functional with with suspected metastatic heart mass, pulmonary vasculature and coronary arteries can be evaluated simultaneously with this imaging $(7,8)$. CT may be beneficial for patients who cannot tolerate prolonged supine position and repetitive breath-holds, which are necessary for adequate evaluation in cardiac MRI $\mathrm{CT}$ is the most suitable imaging method for calcified masses.

8F-FDG PET/CT is a reliable and significant imaging tool to distinguish malignancies from benign neoplasms. This study evaluated imaging findings of five cardiac contribution of radiology in patient management.

\section{PATIENTS AND METHODS}

All patients gave informated content for imaging methods. Ethics committee approval was obtained from the ethics committee of our university hospita for the study (approval no : 2021/3295-5658).

Images of 5 patients with cardiac-paracardiac masses who were referred to the radiology department from different clinics between 2018 and 2021 were evaluated retrospectively. Patients' presentation symptoms and first detection methods of masses were noted. X-ray, CT and MRI images were evaluated, and the mean size of the mass, edge features, whether there was an invasion to neighboring structures and radiological diagnostic findings, if any, were specified. Clinical information and imaging findings of the patients are given below.

\section{RESULTS}

\section{Cases presentation}

Tables 1 and 2 summarizes the findings of this study. Patients' presentation symptoms were noted as fever and weight loss for patient 1 , chest pain for patient 2 and 3 , and cough for patient 4 , respectively. The patient diagnosed with myxoma had no complaints. Computed tomography, echocardiography, and chest X-ray were used for the detection of masses. Diagnosed masses with lymphoma, pleomorphic sarcoma, and hemangioma were larger than $3 \mathrm{~cm}$. The tumors diagnosed with lymphoma and pleomorphic sarcoma had irregular contours and signs of invasion into adjacent structures. Radiological specific findings helped us to diagnose hemangioma, pericardial cyst,

and myxoma.

A 61-year-old female presented to internal medicine with persistent fatigue, fever and night sweats for a month. Since the patient had anemia in routine laboratory tests, thorax and abdominal CT was performed to investigate malignancy. Tomography showed a mass which is extended up
to the vena cava inferior $(\mathrm{VCl})$ and accompanied by

Table 1. Presentation symptoms of patients and first detection methods of masses according to the pathological diagnosis.

\begin{tabular}{llll} 
Table 1. Presentation symptoms of patients and first detection methods of masses according to the pathological diagnosis. \\
\hline Patient & Diagnosis & Presentation symptoms & Mass detection method \\
\hline 1 & Diffuse B-cell lymphoma & B Symptoms & Computed tomography \\
2 & Pleomorphic sarcoma & Dispnea, chest pain & Echocardiography \\
3 & Hemangioma & Breathlessness, chest pain & Echocardiography \\
4 & Pericardial cyst & Persistent cough & Chest X-ray \\
5 & Myxoma & None & Computed tomography \\
\hline
\end{tabular}

Myxoma Non

Computed tomography

Table 2. Imaging features of masseg Diagnosis Mean size Invasion Margin of mas

Invasion
+
+
-
-

IIIl- defined
IIll-defined

Pericardial cyst

$>3 \mathrm{~cm}$

Myxoma

$<3 \mathrm{~cm}$
$<3 \mathrm{~cm}$

Well-defined

Well-defined
Well-defined

enlarged mediastinal lymph nodes in the patient's interatrial septum. 18F-FDG PET/CT was performed. FDG uptake of the mass in the interatrial septum was significant (figure 1). The diagnosis was diffuse B-cell lymphoma after cardiac catheterization and transvenous biopsy.

\section{Patient 2}

A female patient aged 47 years consulted the cardiology department with dyspnea and chest pain symptoms. She had mitral valve replacement history. Echocardiography finding was consistent with a tumor inside the left atrium extended up to the left ventricle. Computed tomography imaging of the heart revealed a mass in the left atrium to left ventricle myocardium

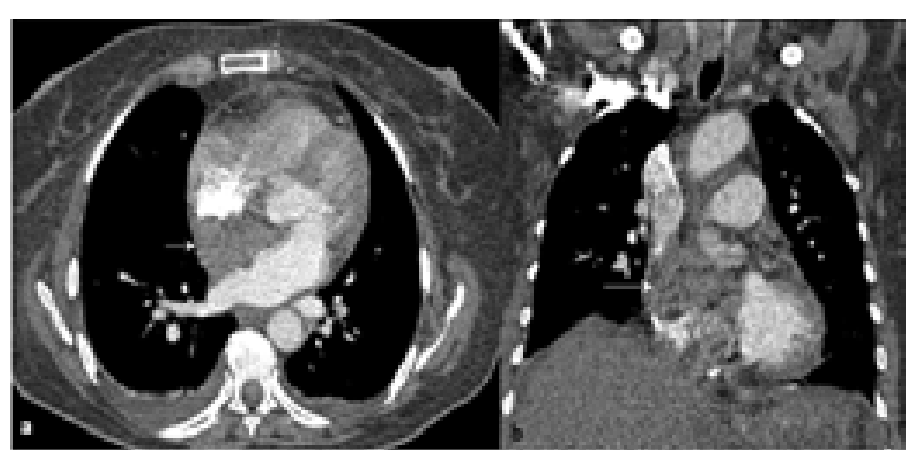

Figure 1. A 61-year-old woman with cardiac ymphoma (patient 1). A. axial B. coronal contrast enhanced CT images show a mass in the interatrial septum extending into vena cava superior (arrows). and obstructing the pulmonary veins (figure 2). In surgery, partial resection was performed for the tumo due to invasion. The pathological diagnosis was highgrade pleomorphic sarcoma.

Patient 3

A female patient aged 49 years presented to pulmonary medicine with breathlessness and ches pain for three weeks. No abnormality was found in her medical history and physical examination. However, her chest X-ray showed cardiomegaly. Transthoracic echocardiogram showed a heterogeneous hyperechoic mass with pericardial effusion next to her left ventricle. Non-enhanced computed tomography revealed a heterogeneous centrally hypodense solid

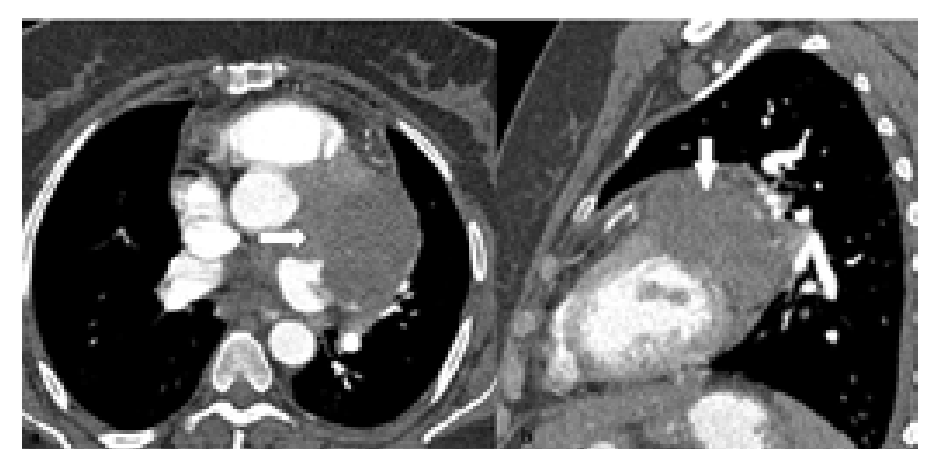

Figure 2. High-grade pleomorphic sarcoma in a 47-year-old female (patient 2) A, B Axial, sagittal view of mass in the left atrium in relation with left ventricule and obstructing the pulmonary veins. 


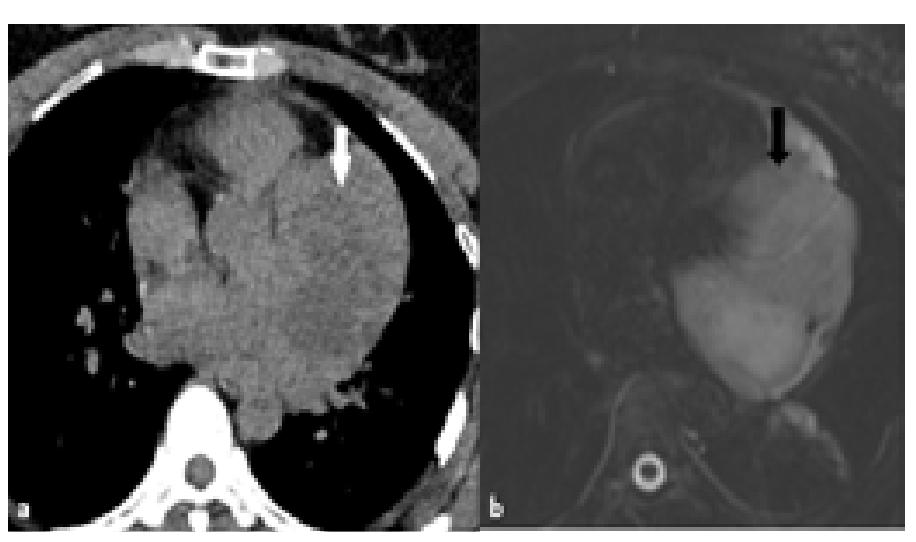
Figure 3. Hemangioma in a 49 years old female
(patient 3). A. Axial nonenhanced CT image shows a heterogeneous centrally hypodense solid mass (white arrow) B. Axial T2 weighted MR image shows a large hyperintense mass (black arrow).

mass adjacent to the left ventricle, the ascending aorta, and pulmonary vessels (figure 3). Pericardial effusion was accompanying the mass.

Cardiac MRI showed that the mass was isointense on T1-weighted images and hyperintense on T2weighted images. Peripheral, nodular, discontinuous enhancement of the lesion was seen during the arterial phase and centripetal filling on venous phases (figure 4).

The preoperative radiological diagnosis was cardiac hemangioma. After complete resection of the mass, the pathological diagnosis confirmed the radiological diagnosis. In addition, pericardial effusion was not hemorrhagic.

Patient 4

A 13-year-old boy presented to the pediatrics

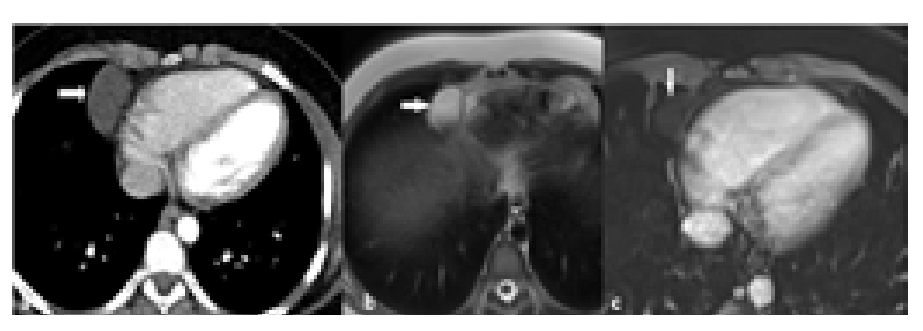

Figure 5. Pericardial cyst in a 13 years old boy (patient 4). A. Axial contrast enhanced CT B. Axial T2 weighted MRI C. Axial contrast enhanced MR images show a well circumscribed cyst in contact with right cardiac margin (arrows).

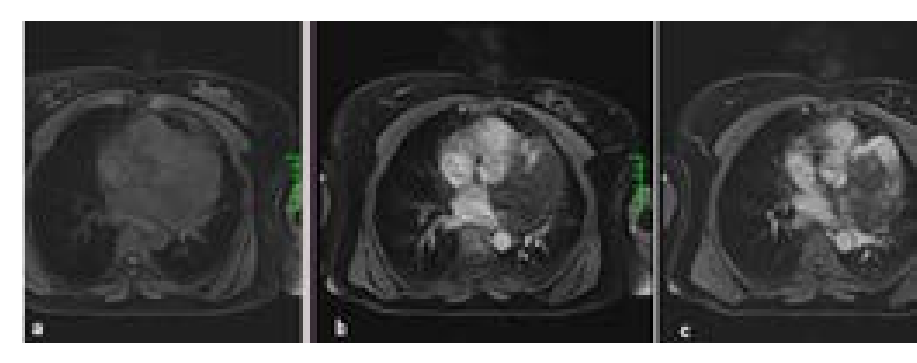

Figure 4. Hemangioma in a 49 years old female (patient 3). A, B, C. Dynamic contrast enhanced MR images show peripheral, nodular, discontinuous enhancement of the mass with centripedal filling on venous phases.

department with a persistent cough. In the physical exam, no abnormality was found. Chest $X$-ray showed an abnormal right cardiophrenic opacity adjacent to the right atrial border. CT performed to determine the nature of this mass revealed a cyst on the right pericardial border. MRI revealed a well-circumscribed cyst in contact with the right cardiac margin (figure 5). This location is classic for a pericardial cyst.

Patient 5

A 64-year-old female patient who had been diagnosed with endometrial carcinoma three years ago underwent chemotherapy after hysterectomy and salpingo-oophorectomy. Chest CT imaging performed for periodic follow-up revealed oval-shaped hypodense, and lobulated contours of intracardiac mass that are localized in the left atrium (figure 6 ).

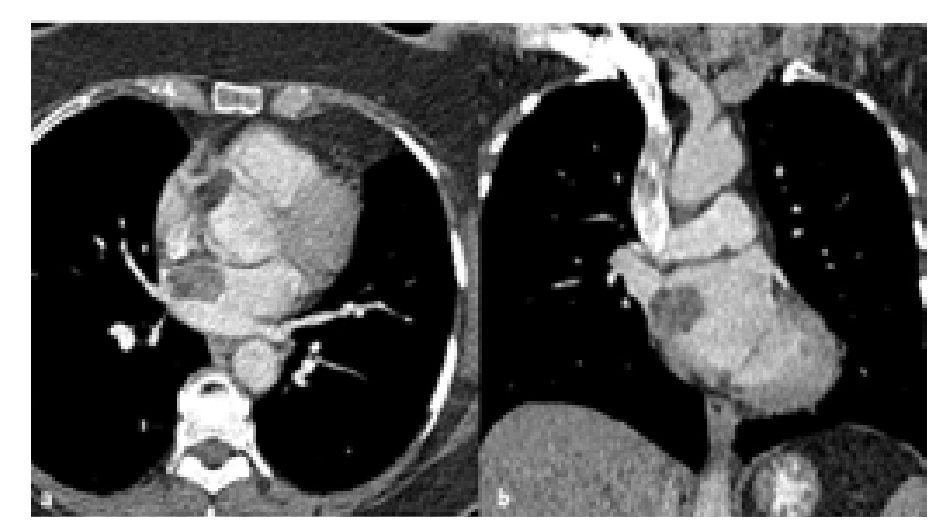

Figure 6. Atrial myxoma in a 64 years old female (patient 5). A, B. Axial and coronal contrast enhanced CT images show oval shaped hypodense mass in left atrium.
Histopathological findings after surgical removal of the mass, which did not show FDG uptake on PET$\mathrm{CT}$, made the diagnosis of myxoma.

\section{DISCUSSION}

Cardiac masses are rare and can be classified as neoplastic and non-neoplastic. Metastatic cardiac tumors are more common than primary malignant tumors. Among primary tumors, benign tumors are more common than malignant ones, and half of these are myxomas $(1,2)$ Imaging has a crucial role in the diagnosis and surgical planning of cardiac mass the

Presis and surgical planning of cardlac masses.

Presentation symptoms for cardiac masses are nonspecific. Similarly, in our cases, symptoms did not suggest the presence of a cardiac tumor. Patient 1 had systemic symptoms of lymphoma. Patients 2 and 3 had symptoms such as dyspnea and chest pain due to the large size of the mass, space-occupying effect, and the compression is created. In patients 4 and 5 , masses were detected incidentally on imaging. Cardiac lymphoma is a rare type of non-Hodgkin's lymphoma (NHL), and its incidence is less than $0.01 \%$ among all cardiac tumors $(9,10)$. In patient 1 , malignancy was considered due to the large size of the mass, its extension to the inferior vena cava on imaging, and accompanying lymphadenopathies in the tomography Thus histopatholo in the tom a in In patient 2, the diagnosis was considered as malignant sarcoma because of the size of the mass detected on echocardlography and its relationship with major vascular structures. Sarcomas are the most common primary malignant cardiac tumors. Symptoms are nonspecific, such as dyspnea, chest pain, and signs of heart failure caused by local invasion (11). CT and MRI are used to evaluate the extension of the mass, its relationship with the great vessels, and the presence of distant metastases and surgical planning as a complement to echocardiography. Although surgery is the first treatment option, complete resection is often unavailable, and the average life expectancy remains less than one year $(12,13)$. Partial resection was performed for the mass in patient 2 as well. In patient 3,4 , and 5 , cardiac aith typical imaging findings.

Cardiac hemangiomas are the rarest primary tumors of the heart, accounting for $2.8 \%$ of benign heart masses. Most cardiac hemangiomas are asymptomatic. Patients may have symptoms of dyspnea, chest pain, and arrhythmia, depending on the size, location, and accompanying pericardial effusion. Hemangiomas are isointense or hypointense on T1- and hyperintense on T2-weighted images. They are peripherally enhanced with contrast in the early phase and filled in the late phase of contrast administration. Diagnosis is made with dynamic contrast-enhanced CT and MRI with this typical enhancement pattern (14) Pericardial cysts are rare and detected incidentally (15). It appears as a bulge in the right heart contour in the chest $x$-ray. It is sen as thin illed, sharply circumscribed round, or oval as thin walled, sharply circumscribed round, or oval mericardial cysts is measured as approximaty $40-50$ HU. In MRI, the is measured as approximately 40-50 in inow , hyperintense on T2-weighted images, and show weak contrast enhancement. Follow-up is recommended in asymptomatic patients. Surgical treatment can be planned according to the increase in cyst size or the development of solid components (16). Myxomas are the most common primary cardiac masses. Over $50 \%$ of benign cardiac masses are myxomas (17). It occurs in middle-aged adults and is more common in women (18). Non-invasive and widely used echocardiography is the first choice in the initial evaluation of myxoma. Contrast-enhanced CT shows myxoma as an oval, flat or lobulated hypodense lesion and intracavitary filling dobulated Surgical removal is ind intracavitary filling defect (4). of embolism and sudden death.

\section{CONCLUSION}

Imaging plays a significant role in the diagnosis of cardiac masses, differentiation between benign and malignant, follow-up, determination of treatment options, and surgical planning. Characteristics of different imaging techniques help in the differential diagnosis

Conflict of interest: Authors declare that there is no conflict of interest between the authors of the article.

Financial conflict of interest: Authors declare that they did not receive any financial support in this study.

Address correspondence to: Cengiz Kadiyoran, Necmettin Erbakan University, Meram Faculty of Medicine, Department of Radiology, Konya, Turkey

e-mail: ckadiyoran@hotmail.com

REFERENCES

McAllister Jr HA. Primary tumors of the heart and pericardium . Grebenc ML, Rosado-de-Christenson ML, Burke AP, et al. 
Primary cardiac and pericardial neoplasms: Radiologicpathologic correlation. Radiographics 2000;20:1073-103.

3. Best AK, Dobson RL, Ahmad AR. Best cases from the AFIP: Cardiac angiosarcoma. Radiographics 2003; 23: S141-5.

4. Kassop D, Donovan MS, Cheezum MK, et al. Cardiac masses on cardiac CT: A review. Curr Cardiovasc Imaging Rep 2014;7:9281.

5. Buckley O, Madan R, Kwong R, et al. Cardiac masses, part 1: Imaging strategies and technical considerations. Am J Roentgenol 2011;197:W837-41.

6. O'Donnell DH, Abbara S, Chaithiraphan V, et al. Cardiac tumors: Optimal cardiac MR sequences and spectrum of imaging appearances. Am J Roentgenol 2009;193:377-87.

7. Bernheim A, Gore A, Goyal N. Evaluation of incidental cardiac masses on computed tomography imaging: An algorithmic approach. J Thorac Imaging 2019;34(1):W1-9.

8. Young PM, Foley TA, Araoz PA, et al. Computed tomography imaging of cardiac masses. Radiol Clin North Am 2019;57(1):75-84.

9. Petrich A, Cho SI, Billett H. Primary cardiac lymphoma: An analysis of presentation, treatment, and outcome patterns. Cancer 2011;117(3):581-9.

10. Singh B, Ip R, Ibrahim Al-Rajjal A, et al. Primary cardiac lymphoma: Lessons learned from a long survivor. Case Rep Cardiol 2016;2016:7164829.
11. Alam L, Agrawal K, Kankanala V, et al. Primary cardiac undifferentiated high-grade intimal pleomorphic sarcoma: A case series report. Cardiol Res 2020;11(2):129-33.

12. Hamidi M, Moody JS, Weigel TL, et al. Primary cardiac sarcoma. Ann Thorac Surg 2010;90:176-81.

13. Kim JT, Baek WK, Kim KH, et al. A primary cardiac sarcoma preoperatively presented as a benign left atrial myxoma. Yonsei Med J 2003;30(44):530-3.

14. Perez Rivera CJ, Figueroa Casanova R, Ochoa Bonet $\mathrm{CE}$, et al. Super large cardiac hemangioma in right atrium and inferior vena cava: Case report. J Cardiothorac Surg 2019;14(1):186.

15. Demos TC, Budorick NE, Posniak HV. Benign mediastinal cysts. J Comput Assist Tomogr 1989;13(1):132-3.

16. Matono R, Shoji F, Yano T, et al. Surgical resection of a giant pericardial cyst showing a rapidly growing feature. Interact Cardiovasc Thorac Surg 2010;10(6):1056-8.

17. Amano J, Kono T, Wada Y, et al. Cardiac myxoma: Its origin and tumor characteristics. Ann Thorac Cardiovasc Surg 2003;9(4):215-221.

18. Araoz PA, Mulvagh SL, Tazelaar HD, et al. CT and MR imaging of benign primary cardiac neoplasms with echocardiographic correlation. Radiographics 2000;20:1303-19. 